\section{Fallopian Tube} Single Cell Dissociation

JUN 11, 2021

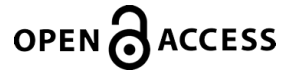

\section{DOI:}

dx.doi.org/10.17504/protocol s.io. bmbbk2 in

\section{Protocol Citation: Nicole} Ulrich, Yu-Chi Shen, Sue Hammoud 2021. Fallopian Tube Single Cell Dissociation Protocol. protocols.io https://dx.doi.org/10.17504/p rotocols. io. bmbbk2 in

\section{License: This is an open} access protocol distributed under the terms of the Creative Commons Attribution License, which permits unrestricted use, distribution, and reproduction in any medium, provided the original author and source are credited

\section{Protocol status: Working} We use this protocol and it's working

Created: Sep 12, 2020

Last Modified: Jun 11, 2021

PROTOCOL integer ID: 42051

Keywords: fallopian tubes, single cell dissociation, dissociation, digestion

\section{(3) Fallopian Tube Single Cell Dissociation Protocol}

Nicole Ulrich ${ }^{1}$, Yu-Chi Shen ${ }^{1}$, Sue Hammoud ${ }^{1}$

${ }^{1}$ Hammoud Lab, University of Michigan

female_repro_tract<smiles>C1CCCCCC1</smiles>

Nicole Ulrich

\section{ABSTRACT}

This protocol describes the single cell dissociation of cells from fallopian tubes.

The single cell dissociation protocol for myometrial cells can be found here.

\section{ATTACHMENTS \\ Fallopian Tube Single Cell \\ Dissociation Protocol.pdf}

\section{MATERIALS}

\section{Stocks}

- PBS/0.04\% BSA (filtered through $40 \mu \mathrm{m}$ )

- DMEM $/ 10 \%$ FBS

- Hyaluronidase ( $[\mathrm{M}] 150 \mathrm{mg} / \mathrm{mL}$, stored in $8^{\circ}-20^{\circ} \mathrm{C}$ ) (Worthington)

- Collagenase IV ( [M] $100 \mathrm{mg} / \mathrm{mL}$, stored in $\left.8^{\circ}-20^{\circ} \mathrm{C}\right)$ (Worthington)

- DNase I ( [M] $10000 \mathrm{U} / \mathrm{mL}$, stored in $88^{\circ}-20^{\circ} \mathrm{C}$ ) (Sigma Aldrich)

- \ $10 \mathrm{~mL}$ Pronase solution ( $\triangle 10 \mathrm{~mL}$ Optimem with \& $18 \mathrm{mg}$ pronase

\section{Additional reagents:}

- HBBS

- Miltenyi Red Cell Solution

\section{SAFETY WARNINGS}

(4) For hazard information and safety warnings, please refer to the SDS (Safety Data Sheet). 


\section{Prep}

Per tissue sample ( \ $100 \mathrm{mg}$ - \ $200 \mathrm{mg}$ tissue) prepare:

- I $10 \mathrm{~mL}$ Pronase solution per each sample of isthmus and ampulla tissue

- \ $20 \mathrm{~mL}$ digestion buffer - make stock solution fresh, warm to $8^{\circ} 37^{\circ} \mathrm{C}$ before use

i. I $20 \mathrm{~mL} \mathrm{HBBS}$, I $300 \mu \mathrm{L}$ collagenase IV , I $132 \mu \mathrm{L}$ hyaluronidase and

\section{\ $40 \mu \mathrm{L}$ DNase 1}

ii. \& $10 \mathrm{~mL}$ digestion buffer per $50 \mathrm{ml}$ falcon tube for each digestion step

- I $8 \mathrm{~mL}$ Miltenyi Red Cell solution or $\& 1 \mathrm{~mL}$ per

I $100 \mu \mathrm{L}$ of cell suspension ( $1: 10$ with double distilled $\mathrm{H}_{2} \mathrm{O}$ )

- Aliquot DMEM/ [M] $10 \%$ FBS

i. I $30 \mathrm{~mL}$ for isthmus and ampulla

ii. I $20 \mathrm{~mL}$ for fimbria

iii. I $5 \mathrm{~mL}$ for resuspension

\section{Fallopian tube single cell dissociation}

1 Each anatomic segment arrives in a separate tube in HBSS, at $8^{\circ}$ Room temperature

2 Weigh and bivalve each fallopian tube segment, but do not "mince" ( I $100 \mathrm{mg}$ I $200 \mathrm{mg}$ tissue pertube).

3 Place only isthmus/ampulla tissue (not fimbria) in $\triangle 10 \mathrm{~mL}$ pronase ( $\triangle 100 \mathrm{mg}$ I $200 \mathrm{mg}$ tissue per tube) and place on $88^{\circ} 37^{\circ} \mathrm{C}$ shaker, (5) $200 \mathrm{rpm}$, 00:05:00 (3) 00:10:00

$4 \quad$ Filter cell suspension \#1 for isthmus and ampulla using a $70 \mu \mathrm{m}$ filter, remove tissue and place in the digestion tube.

5 Rinse filter with \ $10 \mathrm{~mL}$ DMEM/FBS . This is important for quenching the digestion. 
6 Spin filtrate \#1 at $\because 400 \times \mathrm{g}, 00: 04: 00$, resuspend pellet in $\Omega 100 \mu \mathrm{L}$ DMEM/FBS , place $8^{\circ}$ On ice

7 Suspend bi-valved tubal segment tissue (all segments) in individual labeled tubes of digestion buffer. ( I $10 \mathrm{~mL}$ pre-warmed digestion buffer with \& $100 \mathrm{mg}$ - I $200 \mathrm{mg}$ tissue ). Place on $8^{\circ} 37^{\circ} \mathrm{C}$ shaker, (5) $200 \mathrm{rpm}, 00: 30: 00$

8 After 00:30:00 strain cell suspension \#2 using a $70 \mu \mathrm{m}$ filter, remove remaining tissue from filter and place back in digestion tube.

9 Rinse filter with $\triangle 10 \mathrm{~mL}$ DMEM/FBS to quench.

10 Spin filtrate \#2 at $\because 400 \times$ g, 00:04:00 , resuspend pellet in $\Omega 100 \mu \mathrm{L}$ DMEM/FBS , place $\because \quad$ i̊ On ice

11 Repeat digest for an additional 00:30:00 with fresh digestion buffer from stock.

\section{go to step \#7}

12 After $\circlearrowleft$ 00:30:00 (60 minutes total digestion) filter cell suspension \#3 using a 70 um filter.

13 Rinse filter with $\triangle 10 \mathrm{~mL}$ DMEM/FBS to quench. Spin the filtrate at $\because: 400 \times \mathrm{g}, 00: 04: 00$ resuspend pellet in $\triangle 100 \mu \mathrm{L}$ DMEM/FBS, place $\ell^{\circ}$ On ice 
14 Combine cell suspensions $\AA^{\circ}$ On ice from supernatants 1-3 (ampulla and isthmus) or 2-3

4 (fimbria - no

pronase step) in one FACS tube for each segment for a total of $\triangle 300 \mu \mathrm{L}$ for ampulla and isthmus, and \& $200 \mu \mathrm{L}$ for fimbria.

\section{Red Cell Removal}

15 Add $\triangle 1 \mathrm{~mL}$ red cell solution per $\triangle 100 \mu \mathrm{L}$ in each tube for each anatomic section (fimbria, isthmus, ampulla).

16 Vortex $\circlearrowleft 0: 00: 05$ and incubate $\circlearrowleft 0: 02: 00$ at $8^{\circ}$ Room temperature

口

17 Centrifuge $\because 400 \times \mathrm{g}, 00: 04: 00$. Remove supernatant and discard.

ஒ

18 Re-suspend in $\triangle 500 \mu \mathrm{L}$ DMEM or can proceed to washes.

\section{Washes}

19 Wash 3 times with $\triangle 2 \mathrm{~mL}$ PBS/0.04\% BSA in a FACS tube. Spin at $\because 300 \times \mathrm{g}, 00: 03: 00$ in

\& between washes.

19.1 Wash with $\triangle 2 \mathrm{~mL}$ PBS/0.04\% BSA in a FACS tube. (1/3) 
19.2 Spin at $\because 300 \times \mathrm{g}, 00: 03: 00 \cdot(1 / 2)$

19.3 Wash with $\triangle 2 \mathrm{~mL} \mathrm{PBS/0.04 \%} \mathrm{BSA} \mathrm{in} \mathrm{a} \mathrm{FACS} \mathrm{tube.} \mathrm{(2/3)}$

19.4 Spin at $\because 300 \times \mathrm{g}, 00: 03: 00 \cdot(2 / 2)$

19.5 Wash with $\triangle 2 \mathrm{~mL} \mathrm{PBS} / 0.04 \% \mathrm{BSA}$ in a FACS tube. (3/3)

20 Use $40 \mu \mathrm{m}$ to filter after last wash.

21 Re-suspend pellet in $₫ 1 \mathrm{~mL}$ DMEM/10\%FBS .

22 Add DAPI at 1:500 for flow cytometry analysis for live/dead.

\section{To make slides after sorting}

23 Apply \& $30 \mu \mathrm{L}$ single cell solution to the slide and allow slide to dry in the incubator for (7) 00:20:00- 00:30:00 
24 Draw wax circles.

25 Fix with [M] 4\% PFA $x$ 00:05:00

26 Wash $2 \times \circlearrowleft 0: 05: 00$ in PBS, store at $\mathscr{B}^{\circ} 4^{\circ} \mathrm{C}$.

in 